\title{
Wax Myrtle Biology and Control in Pastures ${ }^{1}$
}

\section{Brent Sellers, J. Ferrell, and Reyna Speckmann²}

Southern wax myrtle (Morella cerifera), also commonly referred to as wax myrtle or, simply, myrtle, is a commonly found evergreen shrub/small tree (Figure 1). Native to Florida, this plant is often found in fencerows, pond and marsh edges, pine plantations, hammocks, rangeland, and pastures. While wax myrtle is popular in landscapes and is also important as wildlife habitat, dense infestations can completely eliminate bahiagrass stands (Figure 2). Bahiagrass growth and survival in wax-myrtle infested sites depend upon accurate identification and proper control methods.

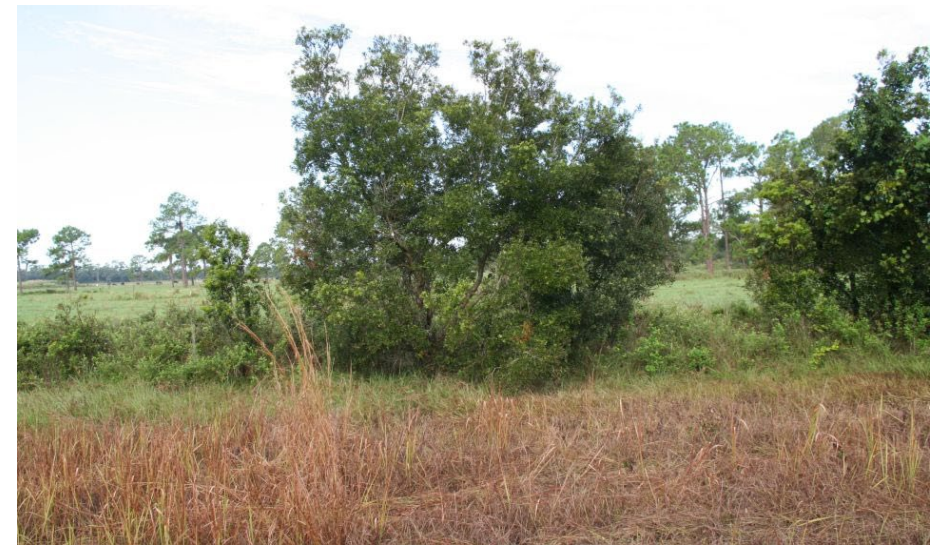

Figure 1. Wax myrtle plants are often found in improved pastures, fencerows, pond, and marsh edges, as well as in native rangeland. This 2009 photo pictures wax myrtle growing in a pasture at the University of Florida's Range Cattle Research and Education Center in Ona, FL. Credits: Brent Sellers, IFAS/UF

\section{Biology}

Wax myrtle is a woody shrub/tree that typically ranges from 15 - 20 feet in height, but can be found as large as 35 feet in height and spread. Leaves are simple, alternate, olive-green in color, and dotted with small, rusty-looking glands on both sides. Overall, the leaves have a wavy appearance (Figure 3) and are aromatic when crushed.

Young stems are light green to gray and hairy. The bark, even with age, is relatively thin and grayish-white in appearance (Figure 4). Individual plants typically have multiple trunks, and new stems appear frequently from the trunk base and roots.

In the spring, wax myrtle produces very small green flowers arranged in cylindrical clusters around individual branches (Figure 5). Immature green fruit (Figure 6) become round, fleshy, and blue, and measure less than 0.5 inches at maturity. The fruit attracts birds, which are the main dispersal mechanism for wax myrtle.

Wax myrtle does not grow well in soils that are extremely dry or wet, nor does this plant grow well in sites that are extremely nutrient deficient. Many Florida soils are sandy, acidic and infertile, requiring at least some level of fertilization for forage production. Considering that low-level fertilization enhances wax myrtle growth, the plant tends to be more problematic in improved pastures than in native or unimproved rangeland.

1. This document is SS-AGR-326, one of a series of the Agronomy Department, Florida Cooperative Extension Service, Institute of Food and Agricultural Sciences, University of Florida. Original publication November 2009. Reviewed December 2012. Visit the EDIS website at http://edis.ifas.ufl.edu.

2. Brent Sellers, assistant professor, Range Cattle Research and Education Center (RCREC)--Ona, FL; J. Ferrell, associate professor, Department of Agronomy; and Reyna Speckmann, Extension scientist, (RCREC)--Ona, FL, Institute of Food and Agricultural Sciences, University of Florida, Gainesville, FL 32611 . 


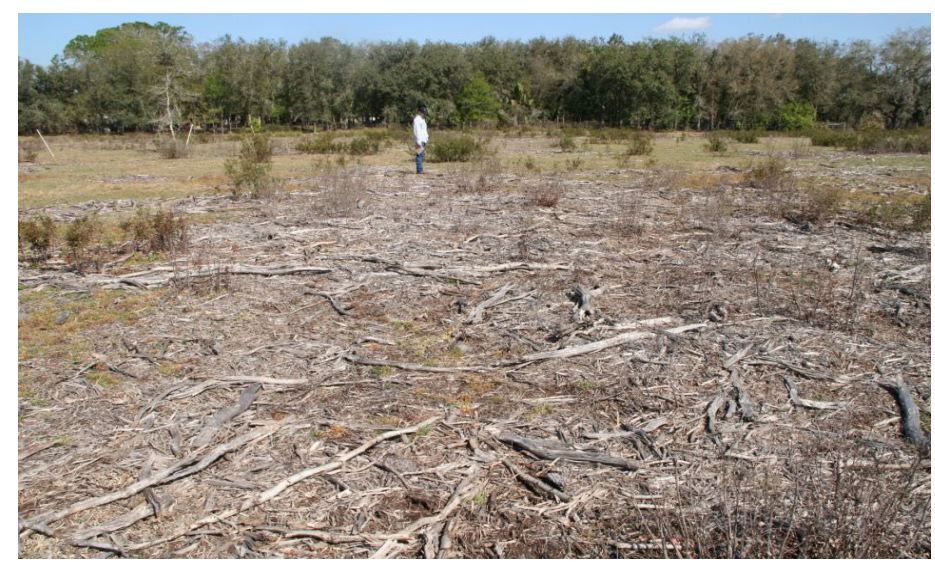

Figure 2. Large, dense areas of wax myrtle can completely eliminate forage growth. This 2008 photo pictures a bahiagrass pasture near Okeechobee where wax myrtle plants were removed approximately seven months earlier. The plants were removed by a skid-steer loader (Bobcat), equipped with a chipper/shredder.

Credits: Brent Sellers, IFAS/UF

\section{Control}

Controlled burning. If wax myrtle has become problematic in rangeland, the level of controlled burns is likely to be insufficient. Research conducted in the late 1970s showed that burning rangeland every two to three years provided excellent suppression of wax myrtle growth. This interval of burning provides sufficient fuel to carry the fire up into the wax myrtle canopy. In pastures (especially bahiagrass), however, fuel is typically insufficient to carry the fire into the wax myrtle canopy, particularly in late winter.

Mechanical control. Prior to the use of herbicides, rollerchopping or some other method was used for wax myrtle control. As with other weeds, however, mechanical treatment only provides temporary control and is not generally cost effective. Wax myrtle plants grow at least 2 inches every 30 days; therefore, chopping will result in temporary control, but plants can be at least 12 inches tall six months after treatment.

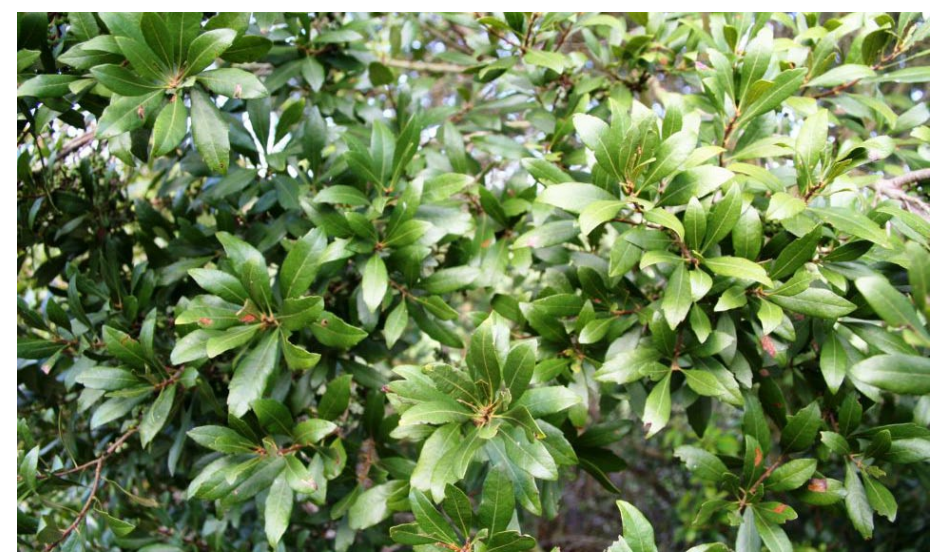

Figure 3. Wax myrtle leaves are typically wavy, 2 - 4 inches long, and have two to three blunt teeth near the tip of the leaf.

Credits: Brent Sellers, IFAS/UF
Chemical control. Control of wax myrtle with herbicides can be a daunting task, considering the immense variability in sizes of wax myrtle within a given pasture or rangeland. Furthermore, wax myrtle plants more than 30 inches tall are more difficult to control than smaller wax myrtle plants. Therefore, if a pasture contains a number of plants more than 30 inches tall, wax myrtle plants should be chopped prior to treatment with herbicides. The fast growth rate of wax myrtle allows for spring chopping or mowing, followed by herbicide treatment in the fall. Our research shows that spring chopping followed by fall application of 1 quart/ acre Remedy Ultra (applied with a water volume of 20-30 gallons per acre) provides $80 \%$ myrtle control 12 months after treatment.

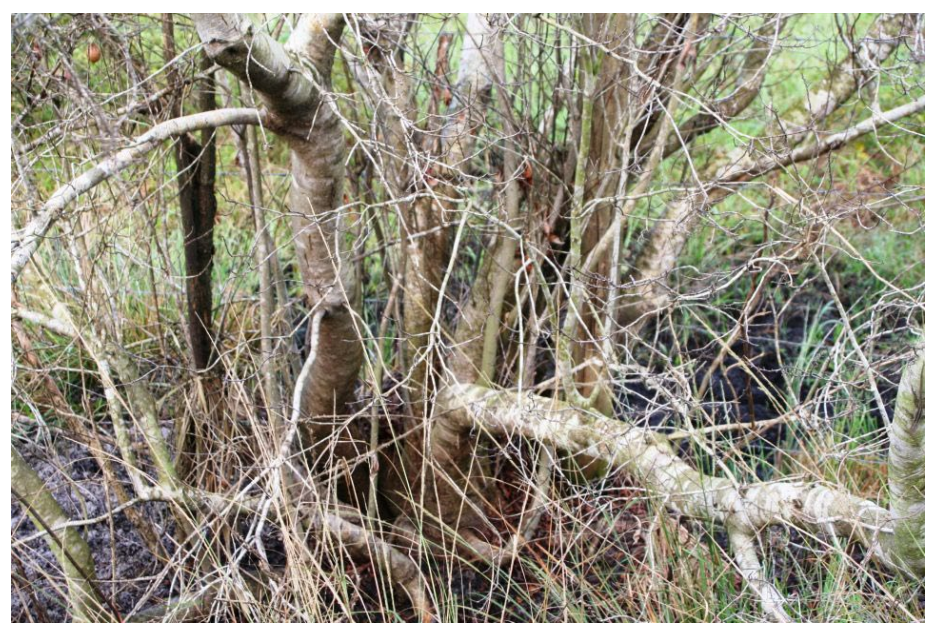

Figure 4. Wax myrtle bark is typically grayish-white and relatively thin, making basal-bark applications of herbicide a feasible option.

Credits: Brent Sellers, IFAS/UF

With very large plants, for which broadcast herbicide application is not feasible, use basal or cut-stump applications of Remedy Ultra. Successful basal-bark applications require a trunk size that is less than 6 inches in diameter. Remedy Ultra mixed in a 1-to-3 ratio with basal oil (1 qt Remedy Ultra +3 qt basal oil) should be applied to the lower 12-18 inches of the myrtle trunks. Adequate control depends upon all trunks within a cluster being treated. For cutstump applications, a 25\% Remedy Ultra solution (in water) should be applied to a freshly cut surface. The herbicide solution must be applied to the cut stump within 15 minutes of cutting the wax myrtle to ensure penetration to the roots. (For more information on techniques for control of woody plants, refer to EDIS Publication SS-AGR-260, Herbicide Application Techniques for Woody Plant Control, http://edis.ifas.ufl.edu/AG245.) 


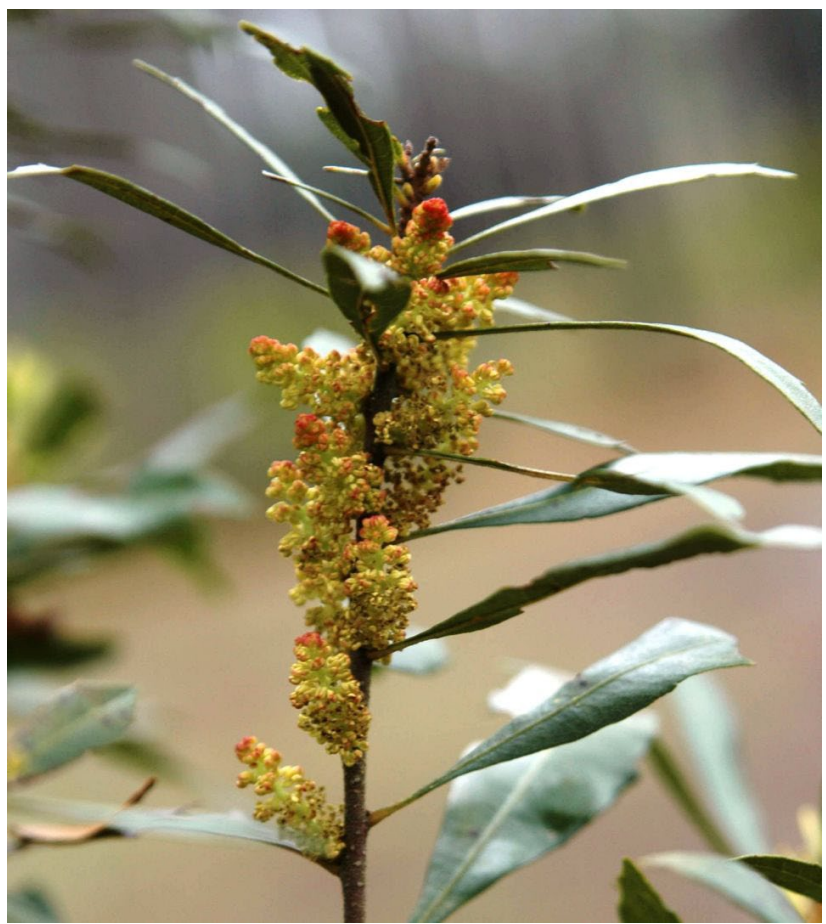

Figure 5. Wax myrtle flowers are green and arranged in cylindrical clusters.

Credits: Chris Evans, River to River Cooperative Weed Management Area (Bugwood.org)

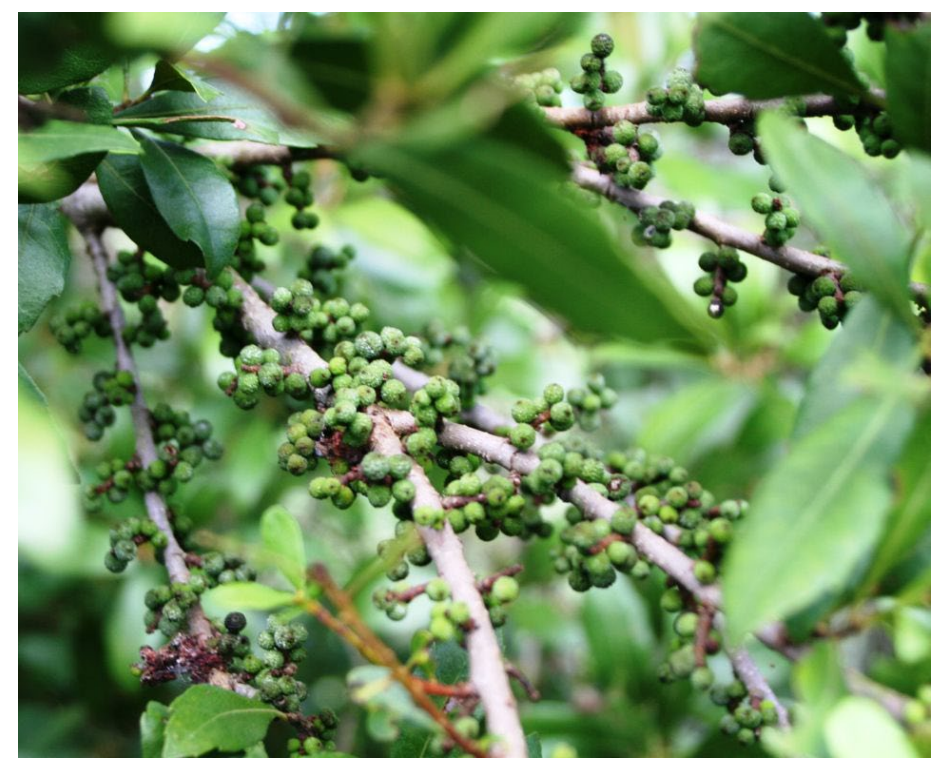

Figure 6. Immature wax myrtle fruits are green. Blue, fleshy, mature fruits attract birds for dispersal.

Credits: Brent Sellers, IFAS/UF 